\title{
TAYANGAN ARKEOLOGI DI TELEVISI: Catatan Ringan Tentang Sebuah Peluang ${ }^{1}$
}

\author{
Marlon NR Ririmasse \\ Balai Arkeologi Ambon \\ Jl. Namalatu-Latuhalat 97118 \\ Email : ririmasse@yahoo.com
}

\begin{abstract}
Abstrak
Fenomena selama dekade terakhir menunjukan kecenderungan meningkatnya tayangan bertema arkeologi pada televisi nasional dan lokal di Indonesia. Meskipun kuantitas dan kualitasnya masih jauh dibanding tayangan sejenis di kanal-kanal internasional, kemajuan ini perlu direspon secara positif. Tulisan ini mencoba mengulas fenomena ini sebagai sebuah peluang bagi pengembangan studi arkeologi di Indonesia. Kata kunci: Arkeologi, Televisi, Indonesia
\end{abstract}

\begin{abstract}
It is clear in the last ten years that archaeological content in the national and local television programs has increased positively. Although their quantity and quality is relatively modest compared to the similar programs on the international channels, this progress must be appreciated positively. This article tries to discuss the issue as an opportunity for the development of Indonesian archaeology.
\end{abstract}

Keywords: Archaeology, Television, Indonesia

\section{Pendahuluan}

Menyimak berbagai tayangan pengetahuan arkeologi di televisi selalu memberi rasa yang berbeda. Ada semacam kepuasan tersendiri ketika dunia profesi yang selama ini kita geluti, bisa ditampilkan dengan kemasan yang begitu modern dan segar. Terselip pula rasa kagum tentang bagaimana proses memperoleh pengetahuan masa lalu, yang kadang panjang dan rumit dalam setiap penelitian arkeologi, ternyata bisa dikemas sebagai tayangan yang mudah dinikmati semua kalangan. Namun sayangnya, semua tayangan pengetahuan kelas dunia tersebut umumnya bukan tentang arkeologi Indonesia, dan bukan pula tampil di 
televisi nasional. Hampir semua tayangan ini tampil di saluran berbayar internasional.

Tentu saja hal ini bisa dimengerti mengingat kondisi pasar dan kebutuhan pengguna televisi berbeda antara satu negara dengan negara lainnya. Namun setidaknya, ada satu catatan penting, bahwa suka atau tidak, televisi adalah salah satu sarana yang paling luas dan populer (saat ini) untuk berbagi ilmu pengetahuan termasuk arkeologi kepada publik. Cakupan publik yang begitu luas dan beragam, adalah suatu filter alami untuk eksistensi setiap tayangan pengetahuan di televisi. Sehingga, sudah pada tempatnya jika ragam tayangan bertema spesifik ini ditampilkan dengan kemasan yang memang memenuhi harapan pasar.

Dalam kerangka televisi nasional, memang belakangan tayangan-tayangan yang bertema penjelajahan, petualangan, dan budaya sudah merangkul tema arkeologi dalam beberapa produksinya. Meski intensitasnya masih minim dan belum muncul secara reguler, kondisi ini tentu merupakan sebuah langkah maju yang layak ditindaklanjuti. Apalagi menyimak menjamurnya televisi lokal di berbagai wilayah Indonesia, kiranya membuka cakrawala peluang yang lebih luas.

Tulisan ini disampaikan sebagai pengantar, terutama kepada rekan-rekan kerja arkeologi yang berminat pada aspek pemasyarakatan, guna bertukar pikiran tentang peluang televisi sebagai sarana publikasi. Menyimak semangat beberapa rekan yang selama ini begitu antusias mengembangkan model publikasi berbasis digitasi dan multimedia, rasanya tayangan arkeologi di televisi adalah sebuah harapan yang dalam hitungan waktu bisa terwujud.

\section{Arkeologi dan Televisi: Lagu Lama Kemasan Baru}

Jika kita jeli mengamati, dekade belakangan menunjukan fenomena meningkatnya intensitas tayangan berbasis pengetahuan spesifik seperti arkeologi di televisi. Hal ini dapat ditinjau dari maraknya tayangan dokumenter dengan tema khusus pada kanal-kanal berbayar seperti National Geographic, Discovery Channel, atau BBC Knowledge. Dikemas sebagai satu paket dengan kanal-kanal bertema berita dan hiburan, kehadiran kanal-kanal berbasis dokumenter ini telah mendapat tempat tersendiri di hati konsumen. Siapa di antara kita yang akan menyangkal kualitas produk-produk dokumenter pada beragam kanal berbayar internasional ini? Kematangan proses produksi nyata terlihat dari bobot tayangan yang ditampilkan. Baik dari sisi visual pun konten (Anonim, 2008).

Latar belakang produksi tayangan documenter di atas tentulah komersil, namun harus diakui bahwa eksistensi dan perkembangan pesat tayangan dokumenter dengan tema spesifik seperti arkeologi menunjukan minat publik yang berkembang terhadap model tayangan seperti ini. Jika lebih jauh mengamati pasar produk jenis ini yang juga terus bertumbuh, bisa disimpulkan bahwa minat konsumen pastilah bertumbuh juga. Memang perdebatan masih terus muncul hingga saat ini, utamanya mempertanyakan hakekat dari tayangan-tayangan ini, apakah merupakan produk bertema pengetahuan ataukah hiburan? Secara pribadi menurut penulis, jika tayangan pengetahuan semacam ini bisa dikemas dengan menghibur, maka rasanya perdebatan ini tidak perlu diperpanjang.

Fenomena yang sama juga kita temukan dalam kerangka televisi nasional, di mana pada waktu belakangan, tayangan-tayangan bertema arkeologi makin sering muncul di televisi. Tema arkeologi biasanya dikemas sebagai bagian dari acara-acara bertema petualangan, penjelajahan, jalan-jalan, atau budaya. Meski masih merupakan bagian dari tayangan regular bertema umum, namun intensitas yang meningka dari tahun ke tahun jelas merupakan gejala yang menggembirakan. Artinya ada ruang bagi segenap insan arkeologi Indonesia untuk turut berpartisipasi.

Harus penulis akui bahwa referensi historis dan data statistik jumlah tayangan arkeologi di televisi nasional yang penulis miliki ketika menulis artikel ini masih minim. Namun, pengalaman menyaksikan beberapa tayangan arkeologi di berbagai kanal televisi nasional, mendorong penulis untuk menampilkan topik ini. Interaksi antara arkeologi Indonesia dan televisi nasional memang menunjukan kecenderungan meningkat pada tahun-tahun belakangan. Kemungkinan besar hal ini didorong oleh pertumbuhan jumlah stasiun televisi nasiona yang juga makin meningkat. Sehingga kebutuhan jumlah tayangan dan variasi tema tayangan pun secara alami ikut meningkat. Sepanjang tahun 2008 saja sekian banyak liputan khusus bertema arkeologi ditampilkan televisi nasional. Dan sangat menggembirakan bahwa beberapa rekan juga tampil memberi kontribusi pemikiran pada tayangan-tayangan tersebut. Jika tidak salah beberapa tayangan khusus yang sempat penulis amati diantaranya menampilkan profil situs candi Muaro Jambi, di mana rekan-rekan Balar Palembang dan BP3 Jambi turut berkontribusi. Demikian halnya dengan tayangan Ekskavasi Candi Losari, yang melibatkan rekan-rekan BP3 Jawa Tengah serta Universitas Gadjah Mada. Tentu ada lebih banyak tayangan khusus bertema arkeologi yang mungkin terlewat untuk disebutkan, namun kedua tayangan tadi bisa menjadi catatan bagi kita semua 
Dalam dekade belakangan terlihat kecenderungan bahwa tema arkeologi memang makin sering dirangkul stasiun televisi nasional dalam berbagai tayangan bertema petualangan dan penjelajahan. Tren ini mungkin saja tumbuh sebagai sesuatu yang terinspirasi dari modelmodel tayangan dokumenter yang dikemas secara elegan di berbagai kanal berbayar Internasional. Fenomena ini sekaligus juga menunjukan budaya dengan segala keunikannya adalah tema yang laris di era dunia nyaris nihil batas ini. Keinginan untuk menikmati pengalaman budaya yang berbeda, telah menciptakan pasar baru bagi tayangan bertema pengetahuan dan penjelajahan budaya. Publik dengan mudah dan murah bisa menikmati keajaiban jejak-jejak peradaban secara lebih interaktif, tanpa harus langsung berkunjung. Peluang ini yang kemudian dimanfaatkan oleh rekan-rekan di media, dengan mengemas sedemikian rupa, alam, budaya, dan sejarah Nusantara menjadi suatu produk visual yang menarik untuk dinikmati.

\section{Cakrwala Arkeologi Global untuk TV Lokal}

Berkaca pada kondisi di atas, bolehlah kita tersenyum sejenak menyimak makin luasnya ruang bagi publikasi arkeologi di televisi nasional. Meski tampil lewat tayangan sporadis yang mungkin belum merupakan acara reguler, namun kemunculan tema-tema arkeologis ini wajib mendapat apresiasi. Ibaratnya pintu pertama peluang ini telah terbuka, tinggal bagaimana komunitas arkeologi Indonesia kin menyikapi. Rasanya akan sangat bijak jika langkah awal yang telah terbangun ini ditindaklanjuti dengan upaya untuk membuka ruang kerjasama yang lebih luas dan teratur bersama rekan-rekan TV Nasional. Hal ini tentu bukan perkara membalik telapak tangan, mengingat label nasional yang ada pada televisi, identik dengan kompleksitas beragam tayangan yang berebutan tempat dan memiliki standar tinggi. Namun dengan konsep kerjasama yang jelas, hubungan ini sangat mungkin dikembangkan. Berkaca pada keberhasilan tayangan bertema arkeologis yang telah mendapat tempat di televisi nasional, rasanya model yang sama sangat mungkin dikembangkan pada media-media sejenis di daerah seperti TV lokal.

Fenomena perkembangan TV lokal adalah peluang yang sebetulnya bisa segera ditindaklanjuti di wilayah kerja masing-masing institusi arkeologi. Pertumbuhan jumlah stasiun TV lokal memang menunjukan angka yang luar biasa. Tahun 2004, jumlah stasiun TV lokal di Indonesia masih berkisar pada angka 50 stasiun. Saat ini jumlahnya mencapai hampir 140 stasiun (Salam, 2007). Pertumbuhan yang pesat ini adalah imbas diterapkannya Undang-Undang Penyiaran No 32 Tahun 2002, yang membuka ruang tumbuh kembangnya penyiaran di daerah. Memang harus diakui tidak semua stasiun TV lokal mapan, ada juga yang masih serba darurat dan 'seadanya'. Namun, jika mau ditinjau dengan kacamata positif, rasanya keberadaan TV lokal cukup potensial untuk dirangkul sebagai mitra pemasyarakatan arkeologi. Setidaknya ada beberapa alasan untuk merangkul TV lokal:

TV lokal umumnya memiliki standar yang lebih akomodatif dan kompromis dibanding TV nasional yang cenderung ketat dalam rumit dalam standar tayangannya

- Konten TV lokal umumnya diarahkan bagi tayangan-tayangan yang memiliki latar dan citarasa setempat

- Keberadaan TV lokal yang masih 'baru', umumnya masih fleksibel dalam konsep acara, sehingga cenderung lebih akomodatif terhadap peluang dan ide setempat

Secara psikologis kedekatan wilayah kerja, cukup membantu dalam membangun kemitraan

Tren tayangan bertema dokumenter yang terus berkembang akhir-akhir tentu tidak lepas dari pengamatan TV lokal untuk dikembangkan

Berbeda dengan TV Nasional, yang lebih padat konsep dan padat modal, TV lokal jelas lebih kecil dalam kedua hal tersebut. Kondisi ini tentu membuat standar tayangan TV lokal lebih akomodatif dalam hal konten maupun kualitas. Label 'Lokal' pada TV Lokal agaknya berpengaruh juga pada konten yang ditampilkan. Citarasa dan Isu setempat menjadi tema yang secara reguler diangkat dalam tayangan TV lokal. Sebagai pemain-pemain 'baru' dalam industri media, TV lokal tentu masih dalam proses pengembangan baik konsep acara maupun karakter tayangan. Sehingga sangat mungkin lebih akomodatif dengan peluang dan ide setempat. Demikian halnya jika sebuah TV Lokal berada pada satu wilayah kerja dengan institusi arkeologi, kiranya akan lebih mudah membangun hubungan berdasarkan kedekatan psikologis secara wilayah kerja. Yang paling pokok tentu saja, tren tayangan dokumenter yang berkembang pesat tahun belakangan, tentulah merupakan segmen yang tidak lepas dari pengamatan peluang rekan-rekan TV lokal.

Semua hal yang disebutkan di atas, mungkin bisa menjadi panduan awal bahwa membangun kemitraan dengan TV lokal adalah hal yang sangat mungkin untuk dilaksanakan. Berbagai standar yang cenderung longgar dan psikologi kedekatan wilayah kerja bisa menjadi titik awal membangun sebuah hubungan kerjasama. Ruang-ruang kosong tayangan 
bertema lokal, bisa kita isi dengan pengetahuan arkeologi dan warisan budaya. Iklim kerjasama yang lebih bersahabat pada level TV lokal ini, bisa menjadi ruang yang sejuk bagi baik TV maupun komunitas arkeologi. Dengan standar yang lebih ramah, ruang komunikasi dan tukar ide antar arkeologi dan TV bisa diciptakan, sehingga kesenjangan pemahaman dapat diminimalisasi. Mengamati fenomena ini rasanya konsep kerjasama arkeologi-TV lokal adalah kerjasama yang memang 'sama-sama menang' sifatnya.

Merangkul Mitra, Membangun Citra: Penelitian Sebagai Lokomotif Pertanyaan selanjutnya adalah bagaimana memulainya? Tulisan ini sama sekali tidak dimaksudkan sebagai tinjauan 'how to'. Apalagi dengan keterbatasan pengalaman dalam publikasi arkeologi pun keterbatasan referensi, rasanya tidak bijak jika tip dan solusi dikemukan di sini. Tulisan ini lebih merupakan pengantar untuk membuka ruang diskusi tentang peluang kerjasama publikasi dengan rekan-rekan media di TV baik nasional dan utamanya TV Lokal.

Jiwa dan semangat arkeologi ada pada proses penelitiannya (Henson, 2006). Hanya penelitian yang memiliki kiblat masalah yang jernih, tujuan penelitian yang jelas, kerangka kerja yang terstruktur dengan spesifik, dan dilaksanakan dengan standar penelitian yang prima, yang akan memberi hasil yang memiliki standar tinggi. Penelitian yang berbobot tentu akan lebih memberi makna pada jawaban permasalahan penelitian yang dikemukakan. Penelitian arkeologi (baik isu, kasus, maupun situs) jelas akan menjadi titik awal topik tayangan arkeologis di TV. Kemampuan untuk menampilkan tema yang berbobot dan relevan, akan mempengaruhi minat publik terhadap tayangan. Rekan-rekan di televisi tentu akan lebih banyak bermain pada topik dengan tataran 'selera pasar' yang cenderung komersil. Itu pasti. Karena itu adalah tantangan bagi kita untuk menampilkan topik yang bukan saja menarik (baca: komersil) namun secara substansial juga berkualitas. Topik yang berkualitas, hanya bisa lahir dari penelitian yang juga berkualitas. Minat untuk bekerja sama biasanya akan tumbuh, setelah rekan-rekan media televisi, menilai hasil kerja kita. Dan hasil kerja yang dapat kita sajikan tentulah segenap penelitian yang telah terlaksana.

Rasanya 'usang' jika harus dikatakan bahwa, penelitian bisa diibaratkan investasi tenaga, biaya dan waktu. Sehingga tidak bijak rasanya jika penelitan yang dilakukan pada suatu situs yang sering kali sukar dicapai dan memakan waktu dan biaya untuk dijangkau, ternyata hanya menghasilkan produk penelitian yang apa adanya. Katakanlah, rekaman data verbal yang ala kadarnya, pun data dokumentasi yang seringkali dibawah standar. Produk dokumentasi adalah bahan mentah yang potensial direkayasa kembali untuk konsumsi publik termasuk dalam kerangka kerjasama dengan TV. Sehingga adalah bijak sekiranya porsi dokumentasi dalam penelitian direkam sesuai dengan standar terbaik yang bisa dicapai. Materi yang berkualitas tinggi selalu lebih potensial untuk menghasilkan produk lanjutan yang juga berkualitas tinggi. Tentu dalam kasus tertentu, sekiranya hubungan baik dengan TV telah terbangun, tidak ada salahnya rekan-rekan media dilibatkan dalam proses penelitian. Artinya, perencanaan penelitian juga sejak awa telah memperhitungkan liputan media sebagai salah satu unsur dalam penelitian (Ririmasse, 2005; 2006).

Sebagaimana judulnya, tulisan ini memang hanya sebuah catatan ringan. Mudah-mudahan bisa menjadi sarana bertukar gagasan antar kita sesama insan arkeologi Indonesia. Rasanya sudah waktunya, penampilan pengetahuan arkeologi Indonesia dibenahi menjadi lebih segar. Dan itu hanya bisa dilakukan dengan memberi nuansa dan citarasa kekinian pada semua produk arkeologi. Adalah harapan bersama bahwa produkproduk publikasi kita bisa menjadi karya yang ramah public (Cleere, 1990; Tanudirdjo, 2003; Little, 2002).

Cermin: Popularitas Arkeologi di TV "Popularitas Arkeologi di Publik"?

Kenyataan bahwa eksinstensi arkeologi di publik Indonesia yang hingga saat ini masih menjadi pergulatan, adalah sebuah kenyataan ironis jika dibandingkan dengan popularitas tayangan bertema arkeologi yang makin meningkat. Artinya, meski tayangan bertema arkeologi sendiri makin meningkat frekuensinya di televisi, kondisi ini belum berimplikasi langsung pada apresiasi publik terhadap arkeologi. Persepsi sebagian besar masyarakat masih tetap kabur tentang arkeologi Indonesia.

Jika saatnya nanti arkeologi Indonesia telah mampu secara reguler tampil di TV nasional atau lokal, hendaknya jangan dilupakan bahwa, popularitas di TV kadang lebih merupakan gambaran hubungan baik antara kalangan arkeologi dan institusi stasiun TV, dan belum tentu merupakan represetasi minat dan apresiasi publik pada arkeologi itu sendiri. Pada akhirnya eksistensi Arkeologi Indonesia hanya bisa diakui ketika kita mampu benar-benar hadir sebagai bagian yang tidak terpisah dan memberi makna nyata dalam keseharian masyarakat. 


\section{DAFTAR PUSTAKA}

Anomim. 2008. Perkembangan Televisi di Indonesia. http://seputarpenyiaran.blogspot.com/2008/09/perkembangan-televisi-di-indonesia. $\underline{\mathrm{html}}$

Cleere, Henry F. 1990. Introdudtion: the rationale of archaeological management, dalam Henry F. Cleree (ed), Archaeological heritage management in the modern world. London :unwinHyman.

Greene, Kevin. 2002. Archaeology an Introduction. London: Routledge.

Henson, Don. 2006. Television Archaeology: Education or Entertainment? http://www.history.ac.uk/education/conference/henson.html

Little, Barbara J. 2002. Archaeology as a shared vision, dalam Barbara J. Little (ed) Public benefits of Archaeology. Gainnerville. University Press of Florida. Hlm.3-19

Ririmasse, M. 2005. Jejak dan Prospek Penelitian Arkeologi di Maluku. Dalam Kapata Arkeologi Volume 1 No. 1. Ambon: Balai Arkeologi Ambon. pp. 35-55

Ririmasse, M. 2006. Siklus Informasi Arkeologi: Menuju Pemasyarakatan Hasil Penelitian Arkeologi yang Terintegrasi. Makalah disampaikan dalam Evaluasi Hasil Penelitian Arkeologi 2006.

Salam, Abdul. 2007. Hati-hati Investasi di TV Lokal. http://zkarnain. wordpress.com/2008/09/12/hati-hati-investasi-tv-lokal/

Tanudirdjo, Daud. 2003. Warisan Budaya untuk Semua: Arah Kebijakan Pengelola Warisan Budaya Indonesia di Masa Mendatang. Makalah disampaikan dalam Kongres Kebudayaan V Bukit Tinggi 2003.

(Footnotes)

${ }^{1}$ Naskah awal artikel ini ditulis untuk disampaikan dalam kegiatan Evaluasi Hasil Penelitian Arkeologi 2008 di Manado. 